\title{
Stability of anthralin in liposomal phospholipids
}

\author{
G. Mahrle $^{1}$, B. Bonnekoh ${ }^{1}$, M. Ghyczy ${ }^{2}$, and W. Wiegrebe ${ }^{3}$ \\ 1 Universitäts-Hautklinik, Joseph-Stelzmann-Strasse 9, W-5000 Köln 41, Federal Republic of Germany \\ 2 Nattermann \& Cie GmbH, Köln, Federal Republic of Germany \\ 3 Pharmakologisches Institut, Universität Regensburg, Regensburg, Federal Republic of Germany
}

Received April 2, 1991

Key words: Anthralin - Stability - Phospholipids Liposomes

Autooxidation of anthralin by air can be enhanced by irradiation with UV or visible radiation, by increase in temperature or $\mathrm{pH}$ and by the presence of zinc ions [14]. At the biological level anthralin readily binds to serum albumin and epidermal protein and is then oxidized [10]. Oxidation intermediates, such as anthralin or anthralinfree radicals, may be responsible for the biological effect. Therefore, anthralin should be stable in therapeutical prescriptions, but oxidation in vivo should not be prevented. Anthralin has dual solubility characteristics due to the hydrophilic hydroxyl and carbonyl groups and the lipophilic 10-methylene group [1]. It is, however, relatively unstable in aqueous or alcoholic solutions [7, 11], but relatively stable in white soft paraffin [8].

Liposomes, consisting of phospholipids and forming vesicles in aqueous solutions, have been shown to be ideal carriers and penetration enhancers for some topical dermatological drugs, e.g. glucocorticoids and antimycotics $[3,4]$. We therefore tested anthralin stability in phospholipid liposomes. Two different phospholipid mixtures were used for the formulation of liposomes (Table 1). Formulations 1, 2 and 3 contained mainly phosphatidylcholine and phosphatidylethanolamine, which meant that these liposomes did not carry electrical charges and were mainly lipophilic. Formulation 4 contained a large amount of negatively charged phospholipids resulting in electrically charged liposomes at physiological $\mathrm{pH}$ with hydrophilic characteristics. There was virtually no difference in particle size and lamellarity between the four formulations.

Formulation 3 had a higher content of electrolytes than the other formulations, in which liposomes were fixed in a gel matrix. Liposomes in formulation 3 were mobile in a dispersion, since electrolytes prevent the for-

Offprint requests to: G. Mahrle mation of a gel matrix. The main fatty acids in the phospholipids were linoleic acid (75\%) and linolenic acid $(7 \%)$. The ratio of unsaturated to saturated fatty acids was $9: 1$ in all formulations.

Formulation 2 was enriched with $10 \%$ primrose oil which contained $71 \%$ linoleic acid, $7 \%$ oleic acid, $10 \%$ $\gamma$-linolenic acid, $9 \%$ palmitic acid, $1 \%$ stearic acid, and $2 \%$ other fatty acids [2]. The ratio of unsaturated to saturated fatty acids was $9: 1$, the same as in the original liposomal phospholipids. In addition to the fatty acid composition of formulations 1,3 and 4 , with $7 \% \alpha$ linolenic acid, formulation 2 contained $1 \% \gamma$-linolenic acid.

Fresh $1 \%$ anthralin phospholipid was prepared by incorporation of $50 \mathrm{mg}$ purified anthralin in $5 \mathrm{~g}$ of the vehicle. Purification was by column chromatography $\left(\mathrm{SiO}_{2}\right.$, dichloromethane). During the time of investigation the preparation was stored at $5^{\circ} \mathrm{C}$ under light protection. Samples were taken at different intervals and analysed by thin layer chromatography [15]. C4-lactone, a hydrophilic derivative of anthralin with a lacton ring at position 10, was synthesized as described elsewhere [16]. C4-lactone (derivative X) has been shown to inhibit cell growth in vitro more effectively and to be less toxic than anthralin [5]. It was therefore compared with anthralin, using a $1 \%$ concentration in phospholipids.

We found that anthralin rapidly degraded in formulation 2, less rapidly in formulations 1 and 3, and relatively slowly in formulation 4 (Table 2 ). This meant that there was virtually no difference between the degradation time in the gel or the dispersion formulations 1 and 3 , even though anthralin was less soluble in the dispersion than in the gel. The addition of primrose oil reduced the degradation time. The lowest anthralin degradation rate was obtained with the liposome preparation containing a higher content of negatively charged phospholipids. C4-lactone was more stable than anthralin, at least in formulations 2 and 3.

The results demonstrate that anthralin is oxidized within days in liposomal phospholipids. The oxidation process is retarded by using liposomes consisting mostly 
Table 1. Liposomal phospholipid formulations

\begin{tabular}{lllll}
\hline & \multicolumn{2}{l}{ Formulation } & & \\
\cline { 2 - 5 } & 1 NAT 8257 & $2:$ NAT 8308 & $3:$ NAT 8417 & $4:$ NAT 8418 \\
\hline Phospholipid (wt \%) & $20^{\mathrm{a}}$ & $18^{\mathrm{a}}$ & $19^{\mathrm{a}}$ & $20^{\mathrm{b}}$ \\
Ethanol (wt\%) & 16 & 16 & 16 & 16 \\
Other ingredients (wt \%) & - & $10 \%$ primrose oil & $4 \%$ choline chloride & - \\
Water (wt\%) & to 100 & to 100 & to 100 & 100 \\
Particle size (nm) & $200 \pm 20$ & $200 \pm 20$ & $160 \pm 20$ & $190 \pm 20$ \\
Lamellarity & $4-6$ & $4-6$ & $3-5$ & $2-4$ \\
pH & 6.5 & 6.1 & 5.7 & 7.1 \\
Physical form & Transparent gel & Non-transparent gel & Dispersion & Non-transparent gel \\
\hline
\end{tabular}

a $85 \%$ PC, $10 \%$ PE, $5 \%$ acidic PL; ${ }^{\text {b } 28 \% ~ P C, ~} 2 \%$ PE, $43 \%$ acidic PL, $6 \%$ sterine and derivatives, $21 \%$ soya oil. Abbreviations: PL, phospholipids; PC, phosphatidylcholine; PE, phosphatidylethanolamine. Acidic PL are phosphatidic acid, phosphatidylinositol and $\mathrm{N}$-acylphosphatidylethanolamine

Table 2. Stability of anthralin (C4-lactone) in liposomal phospholipid formulations. + , unaffected or minimally oxidized; \pm , highly degraded; -, completely oxidized; n.d., not done

\begin{tabular}{lllll}
\hline Day & \multicolumn{4}{l}{ Formulation } \\
\cline { 2 - 5 } & 1 & 2 & 3 & 4 \\
\hline 0 & $+(+)$ & $+(+)$ & $+(+)$ & $+(+)$ \\
1 & $+(+)$ & $\pm(+)$ & $+(+)$ & $+(+)$ \\
2 & $+($ n.d.) & $\pm($ n.d.) & $+($ n.d. $)$ & $+($ n.d. $)$ \\
5 & $+(+)$ & $\pm(+)$ & $+(+)$ & $+(+)$ \\
9 & $+( \pm)$ & $\pm( \pm)$ & $\pm(+)$ & $+(+)$ \\
23 & $\pm( \pm)$ & $-( \pm)$ & $\pm( \pm)$ & $+(+)$ \\
36 & $-( \pm)$ & $-( \pm)$ & $-( \pm)$ & $\pm( \pm)$ \\
\hline
\end{tabular}

of negatively charged phospholipids. Compared with other vehicles (Table 3) anthralin in phospholipids was less stable than in white soft paraffin, but more stable than in aqueous or acetone solutions.

\section{References}

1. Ashton RE, Andre P, Lowe NJ, Whitefield M (1983) Anthralin: historical and current perspectives. J Am Acad Dermatol 9:173-192

2. Becker H (1983) Das Öl der Nachtkerze Oenothera biennis. Z Phytother 4:531-536

3. Bonnekoh B, Mahrle G (1990) Die kutane Applikation von Liposomen - Eine Literaturübersicht unter besonderer Berücksichtigung der Befunde von Keratinozytenkulturen, Tierexperimenten sowie klinischen Studien. Z Hautkr 65:99-105

4. Bonnekoh B, Röding J, Krueger GRF, Ghyczy M, Mahrle G (1991) Increase of lipid fluidity and suppression of proliferation resulting from liposome uptake by human keratinocytes in vitro. Br J Dermatol 124:333-340

5. Bonnekoh B, Tanzer H, Seidel M, Geisel J, Merk HF, Wiegrebe W, Mahrle G (1991) Structural - functional relationship of new anthralin derivatives assayed for growth inhibition and cytotoxicity in human keratinocyte cultures. Arch Pharm (in press)

6. Braun C, Wiegrebe W (1988) Notiz zur Haltbarkeit von Dithranol-Salben. Pharmakol Z 133:691-692

7. Cavey D, Caron JC, Shroot B (1982) Anthralin: chemical instability and glucose-6-phosphate dehydrogenase inhibition. J Pharm Sci 71:980-983
Table 3. Stability of anthralin in different vehicles. HLT, half-life time, i.e. the time after preparation at which at least $50 \%$ of anthralin is degraded; LCD, liquor carbonis detergens; DMEM, Dulbecco's modified Eagle's medium

\begin{tabular}{|c|c|c|}
\hline Vehicle & HLT & Reference \\
\hline $\begin{array}{l}\text { White soft paraffin } \\
\quad+\text { coal } \operatorname{tar}(\text { room temp.) } \\
\quad+\text { coal } \operatorname{tar}\left(4^{\circ} \mathrm{C}\right) \\
\quad+\text { LCD }\end{array}$ & $\begin{array}{l}>1 \text { year } \\
<3 \text { weeks } \\
>3 \text { weeks } \\
\text { about } 10 \text { weeks }\end{array}$ & $6,8-10,12$ \\
\hline $\begin{array}{l}\text { Pasta zinci oleosa } \\
\quad+\text { salicylic acid }\end{array}$ & $\begin{array}{l}<1 \text { month } \\
\text { about } 6 \text { months }\end{array}$ & 13 \\
\hline $\begin{array}{l}\text { Aqueous buffer ( } \mathrm{pH} 7.5) \\
\text { Acetone solution }\end{array}$ & $\begin{array}{l}\text { about } 1 \mathrm{~h} \\
<1 \mathrm{~h}\end{array}$ & 7 \\
\hline $\begin{array}{l}0.1 \% \text { acetone in DMEM } \\
\text { (under cell culture conditions) }\end{array}$ & $10 \mathrm{~min}$ & 5 \\
\hline Phospholipids & $\begin{array}{l}<1 \text { day to } \\
<5 \text { weeks }\end{array}$ & Present paper \\
\hline
\end{tabular}

8. Green PG, Forbes DR, Kennedy CTC (1985) The stability of dithranol in various bases. Br J Dermatol 113 [Suppl 29]:26

9. Herman J, Remon JP, DeBersaques J (1988) Influence of storage conditions on the stability of anthralin in the presence of coal tar and salicyclic acid in a white soft paraffin base. J Am Acad Dermatol 18:750 - 751

10. Mahrle G (1987) Anthralin - New treatment modalities and combination regimens. In: Farber EM, Nall L, Morhenn V, Jacobs $\mathrm{PH}$ (eds) Psoriasis. Elsevier, New York Amsterdam London, pp 181-187

11. Melo TSE, Dubertret L, Prognon P, Gond A, Mahuzier G, Santus R (1983) Physicochemical properties and stability of anthralin in model systems and human skin. J Invest Dermatol $80: 1-6$

12. Müller R, Naumann E, Detmar M, Orfanos CE (1987) Stabilität von Cignolin (Dithranol) in teerhaltigen Salben mit und ohne Salicylsäurezusatz. Hautarzt 38:107-111

13. Ponec-Waelsch M, Hulsebosch HJ (1974) Further studies on the interaction between anthralin, salicylic acid and zinc oxide in pastes. Arch Dermatol Res 249:141-152

14. Raab WP, Gmeiner BM (1975) Influence of ultraviolet light, various temperatures, and zinc ions on anthralin (dithranol). Dermatologica 150:267-276

15. Retzow A, Schäublin J, Wiegrebe W (1978) Densitometrische Bestimmung von Anthronen und Anthrachinonen. Pharmakol Z 123:1808-1810

16. Tanzer H, Wiegrebe W (1988) Hydrophilic derivatives of dithranol. Arch Pharm (Weinheim) 321:447-449 